\title{
Radiocarbon dated common mussels Mytilus edulis from eastern Svalbard and the Holocene marine climatic optimum
}

\author{
CHRISTIAN HJORT, JAN MANGERUD, LENA ADRIELSSON, STEIN BONDEVIK, JON Y. LANDVIK and OTTO \\ SALVIGSEN
}

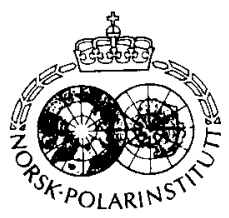

Hjort, C., Mangerud, J., Adrielsson, L., Bondevik, S., Landvik, J. Y. \& Salvigsen O. 1995: Radiocarbon dated common mussels Mytilus edulis from eastern Svalbard and the Holocene marine climatic optimum. Polar Research 14(2), 239-243.

The common mussel Myrilus edulis is an indicator of milder marine conditions in the Arctic. with stronger Atlantic Water influx, during the Holocene and earlier interglacials. Twelve Holocene radiocarbon dates of Mytilus from eastern Svalbard fall between ca 8800 and $5000 \mathrm{BP}$ and roughly delimit the marine climatic optimum period there. The beginning of this period in the east coincides with the immigration of boreal extralimital molluses to western Svalbard, indicating the culmination of Holocene Atlantic influence.

Christian Hjort and Lena Adrielsson, Department of Quaternary Geology, Lund University, Sölvegatan 13, S-223 62 Lund, Sweden; Jan Mangerud and Stein Bondevik, Department of Geology, Section B, University of Bergen, Allégaten 41, N-5014 Bergen, Norway; Jon Y. Landvik, UNIS, N-9170 Longyearbyen, Norway; Otto Salvigsen, Norsk Polarinstitutt, P.O. Box 5072 Majorstua, N-0301 Oslo, Norway.

\section{Introduction}

The common mussel Mytilus edulis L. is mainly an intertidal to shallow sub-tidal bivalve, which spreads with pelagic larvae and byssus drifting. It does not live on Svalbard today, but living specimens attached to seaweed, boxes and other items, presumed to have drifted from the south, have been encountered several times during the last hundred years (Knipowitsch 1903a; Heintz 1926; Peacock 1983; Mangerud \& Bolstad unpubl.).

However, during the warmer parts of the Holocene, Mytilus was common on Svalbard, especially on the western coast (summary in Salvigsen et al. 1992; see Fig. 1). Reports from the colder northern and eastern parts of the archipelago are fewer. In the east, scattered finds had been made earlier on Edgeøya (Knipowitsch 1903b) and on Svenskøya in the Kong Karls Land archipelago (Nathorst 1901; Hägg 1950). Nansen (1902) even found it as far east as Franz Josef Land.

\section{The PONAM expedition}

During the PONAM (Polar North Atlantic Margins, Late Cenozoic Evolution, see Acknowledgements) expedition to eastern Svalbard in
1991, most major sections in Quaternary sediments on Edgeøya and Barentsøya were studied, with extensive work being done also on western Kongsøya in Kong Karls Land. Mytilus was found in raised marine sediments at several localities, but only on Edgeøya (Hjort et al. 1992), where it occurs from ca $45 \mathrm{~m}$ a.s.l. to a few metres above the present shore. In some places it was very common, for example at Habenichtbukta on southwestern Edgeøya, close to Krausshavn where it was found during the Russian expedition in 1899 (Knipowitsch 1903b).

The dated Mytilus samples from Edgeøya and the earlier Svenskøya find are listed in Table 1. Most of the localities and finds were described by Hjort et al. (1992) and also listed by Gulliksen et al. (1992), but four new dated samples, also collected during the PONAM expedition, have now been added. All known occurrences on Edgeøya are indicated on Fig. 2.

\section{Radiocarbon dates}

Eleven radiocarbon dates were made on Mytilus shells collected on Edgeøya during the FONAM expedition 1991 (Table 1). Eight of these were conventional datings made in Trondheim and Lund and three were AMS-datings made in Aarhus or Uppsala. The fragments found on 


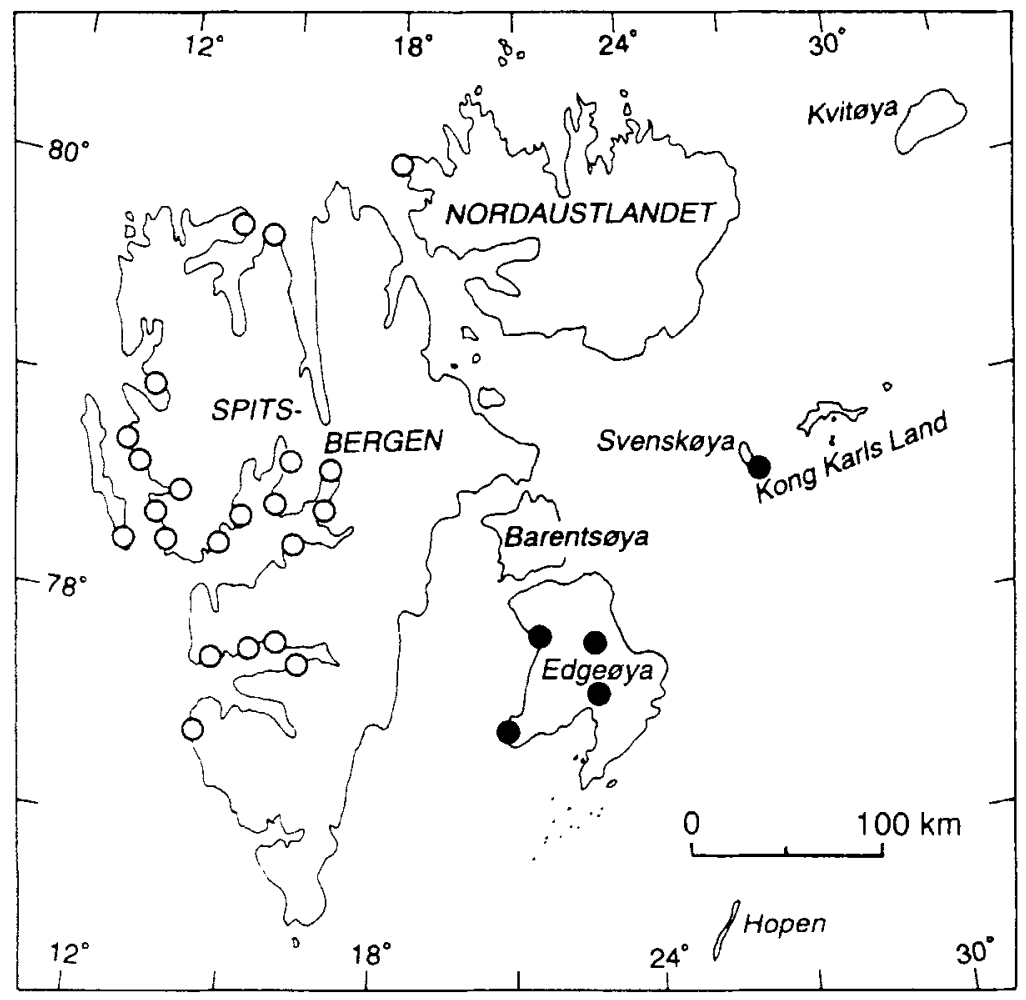

Fig. I. Svalbard, with dated Mytilus edulis finds according to Salvigsen et al. (1992. open circles) and as added through this study (filled circles, details in Fig. 2).

Table 1. Radiocarbon dated Mvrilus edulis samples from eastern Svalbard. Except for no, 4, which is from Kong Karls Land and was collected in 1898 ( Nathorst 1901: Hägg 1950), all samples are from Edgeøya (Fig. 2) and were collected during the PONAM expedition in 1991 (Hjort et al. 1992: Gulliksen el al. 1992). The ages are corrected for a reservoir effect of -440 years (Mangerud \& Gulliksen 1975). $\delta^{1 \mathrm{C}} \mathrm{C}$ is expressed as $\%$ on the PDB scale.

\begin{tabular}{|c|c|c|c|c|c|c|c|}
\hline & Locality & $\begin{array}{l}\text { Sample } \\
\text { no. }\end{array}$ & m a.s.l. & Age $B P$ & ${ }^{1+} \mathrm{C}$ lab. no. & $\delta^{13} \mathrm{C}$ & Collector \\
\hline 1 & Smelledalen & $86-707 \mathrm{D}$ & 40 & $8755 \pm 125$ & T.9919 & -0.2 & J. Mangerud \& S. Bondevik \\
\hline 2 & Blafjorddalen & $88-456$ & 39 & $8510 \pm 120$ & $\mathrm{~T}-9909$ & - & J. Y. Landvik \\
\hline 3 & Ruduedalen & $86-307$ & 36 & $8210 \pm 150$ & AAR-837 & 0.1 & O. Stubdrup \& S. Bondevik \\
\hline+ & Srenskoya & $88-739$ & 25 & $7260 \pm 100$ & AAR-853 & -0.3 & G. Andersson \\
\hline 5 & Seidbreen & $88-735$ & in till & $7205 \pm 115$ & Ua-3279 & - & C. Hjort \\
\hline 6 & Smclledalen & $86-703 \mathrm{~A}$ & 35 & $7175 \pm 110$ & T-9922 & 0.5 & J. Mangerud \& S. Bondevik \\
\hline 7 & Smelledalion & $87-653$ & 37 & $7095 \pm 55$ & Tua-473 & 1.0 & J. Mangerud \\
\hline 8 & Smelledaien & $86-702 \mathrm{~A}$ & 34 & $7095 \pm 135$ & $T-10144$ & 0.3 & J. Mangerud \& S. Bondevik \\
\hline$y$ & Smelledalen & $87-655$ & 15 & $7050 \pm 140$ & $\mathrm{~T}-9921$ & 0.3 & J. Mangerud \\
\hline 10 & Smelledalen & $87-654 C$ & 28 & $6885 \pm 85$ & $T-10145$ & -0.3 & J. Mangerud \\
\hline 11 & Smelledalen & $86-701 \mathrm{~A}$ & 27 & $5835 \pm 125$ & $\mathrm{~T}-9920$ & 0.5 & J. Mangerud \& S. Bondevik \\
\hline 12 & Habenichtbukta & $88-711$ & 4 & $4960 \pm 80$ & Lu-3373 & -0.6 & C. Hjort \& L. Adrielsson \\
\hline
\end{tabular}




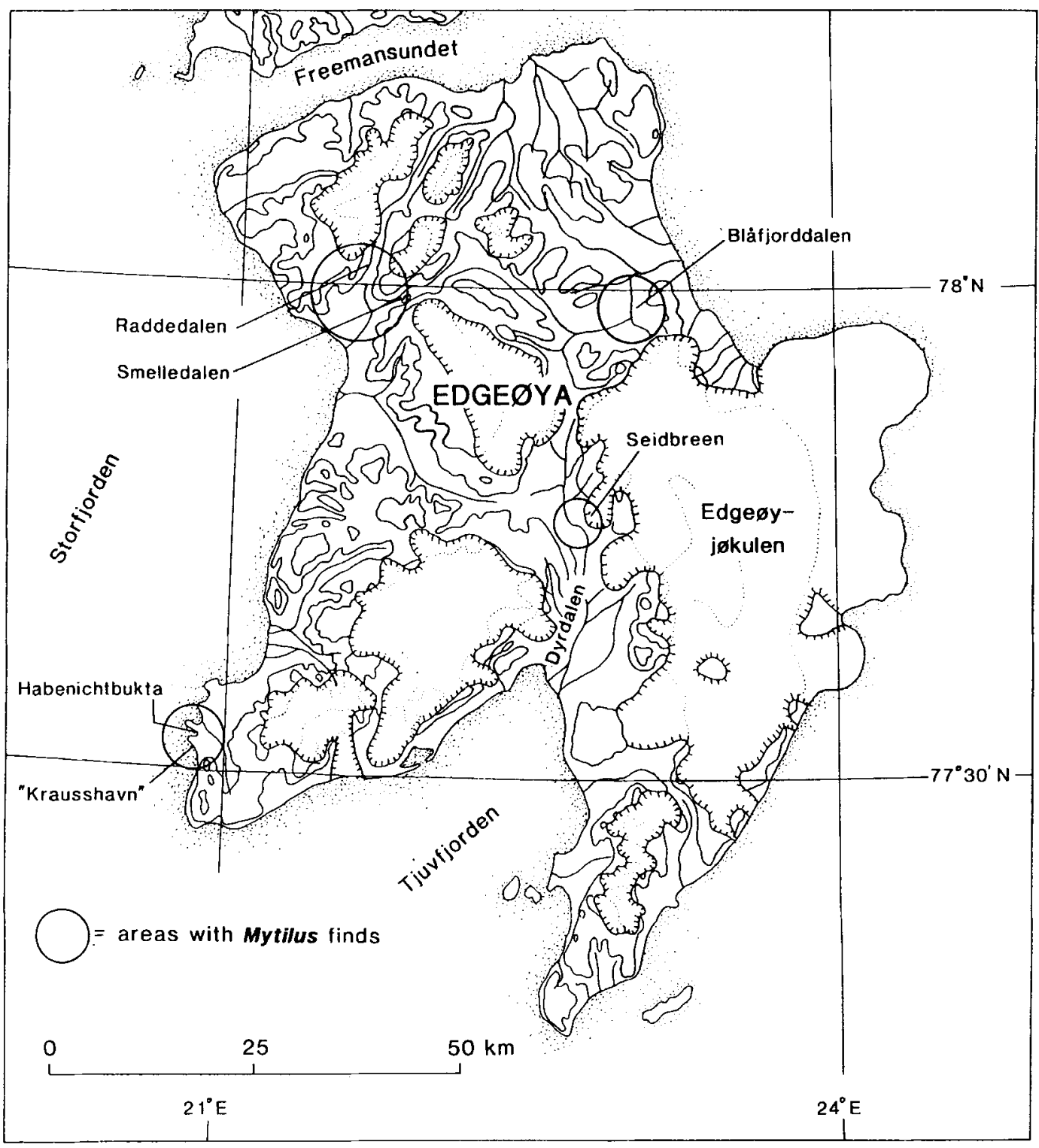

Fig. 2. Edgeøya with known occurrences of Mytilus edulis.

Svenskøya in 1898 were AMS-dated in Aarhus. All samples have been corrected for a reservoir effect of -440 years, according to Mangerud \& Gulliksen (1975).

The oldest shells date from $8755 \pm 125 \mathrm{yrs} \mathrm{BP}$ and belong to those collected at the highest altitudes. The youngest dated shells, from $4960 \pm 80$ $B P$ at Habenichtbukta, were those encountered at the lowest altitude, $4 \mathrm{~m}$ a.s.l. Our datings thus show that Mytilus immigrated to eastern Svalbard not later than ca $8800 \mathrm{BP}$ and was still living there around $5000 \mathrm{BP}$.

\section{Discussion}

\section{Present distribution}

Although Mytilus is not found living on Svalbard today, it penetrates far into southeastern Barents 
Sea (Peacock 1989) and up along the western coast of Greenland (Funder \& Weidick 1991). It even maintains populations on the southeastern coast of Greenland, within waters affected by the cold East Greenland Current (Hjort \& Funder 1974: Funder \& Weidick 1991). It also occurs at scattered localities along the eastern coast of Baffin Island, where Arctic Water flows southward in the Baffin-Labrador Current (Andrews 1972). Mytilus may thus live under conditions where summer sea-surface temperatures (SST's) approach $0^{\circ} \mathrm{C}$. The presence of marginal populations which live today in fjord areas inside coldwater currents (e.g. in the Ammassalik district in southeastern Greenland), indicates an ability to colonise rather local areas with higher than average SST"s. This may occur during years with stronger than average Atlantic Water penetration (cf. discussion in Peacock 1989. p. 189).

\section{Hypsithermal distribution}

Mytilus had a much larger northward distribution during earlier parts of the Holocene and has become the classical exponent for warmer-thanpresent conditions in the Arctic. Svalbard was the area where this first became evident (e.g. Blomstrand 1864: Nathorst 1884: Högbom 1913: Fevling-Hanssen 1955).

According to the review by Salvigsen et al. (1992). it immigrated to the western coast of Svalbard before $9500 \mathrm{BP}$ and lived there until around $3500 \mathrm{BP}$. Thereafter it briefly reimmigrated during the warm period around 1000 BP. Thus it seems to have appeared on eastern Svalbard some $500-900$ vears later than on the western coast. The western and northem coasts are today the areas most affected by Atlantic Water. and that this general pattern prevailed also earlier during the Holocene is, for example. indicated by the mid-Holocene occurrence only on the central western coast of the boreal molluscs Zirphea crispata. Modiolus modiolus, Arctica islandica and Littorina littorea (Feyling-Hanssen 1955: Salvigsen et al. 1992: Mangerud \& Svendsen 1992). According to our radiocarbon dates. the immigration of Mytilus to eastern Svalbard roughly coincided with the first appearance of boreal molluses on the west coast, which took place around 8700 BP (Salvigsen et al. 1992). Thus it seems that it managed to colonise these eastern parts as an effect of a maximum Atlantic Water influx to the region. But Mytilus lived on along the shores of Edgeøya well after the boreal period on the western coast had come to an end, as it did around $7700 \mathrm{BP}$. Nor was our youngest Mytilus date, from ca $5000 \mathrm{BP}$, from a population on the verge of extinction. It then still lived in profusion in a local shallow lagoon environment in Habenichtbukta (Adrielsson et al. 1992).

Today the waters around Edgeøya and Kong Karls Land are dominated by the southwesterly flow of Arctic Water in the East Spitsbergen Current (e.g. Loeng 1991). It seems that a precondition for the immigration of Mytilus into this area, and for its persistence there during ca 4000 years. must have been a weakening of this cold current and a much stronger influx of Atlantic Water than today. The foraminiferal record in marine sediment cores from western Franz Josef Land, northeast of our study area and much further away from the Atlantic source supports this. It indicates that the most favourable marine conditions there, with the strongest Atlantic influence, were between 7000-5000) BP (Polyak \& Solheim 1994). How quickly the balance between warmer Atlantic and colder Arctic waters may indeed shift, over a few decades or less, has recently been documented from the northern coast of Svalbard by Eggertsson (1994), with the help of driftwood studies.

The same pattern of early to mid-Holocene weakening of cold water outflows from the Polar Basin. with a markedly stronger Atlantic influence, has been suggested for both the East Greenland Current and the Baffin-Labrador Current, using Mytilus dates (Andrews 1972; Hjort \& Funder 1974: Funder \& Weidick 1991). A study by Koc \& Jansen (1994), based on oxygen isotope and diatom stratigraphy in deep sea cores from the Greenland Sea, confirms that this enhanced Atlantic influence began to affect the coast of central East Greenland ca $8500 \mathrm{BP}$, which is roughly when Mytilus immigrated (Hjort \& Funder 1974). The Atlantic influence diminished from ca $5000 \mathrm{BP}$, coinciding with the disappearance of Mytilus. This further illustrates the close relationship between oceanographic climatic conditions and the geographic distribution of this pelagically spreading indicator bivalve!

Acknowledgements. - PONAM was a European Science Foundation Arctic Network programme which ran from 1990 to 1994. The Norwegian Polar Institutc, the Swedish Polar Sicretariat and the EEC (through a grant for helicopter costs to the European Science Foundation) supported the expedition logistically and the Norwegian Research Council for Science and Humani- 
ties and the Swedish Natural Science Research Council financed the work connected with this study. The Natural History Museum in Stockholm supplied the Svenskøya shells for dating. J. D. Peacock and K. S. Petersen are thanked for constructive reviews.

\section{References}

Adrielsson. L.. Hjort. C. \& Johansson, K. 1992: A Holocene regression sequence at Habenichtbukta, southwestern Edgeøya. Svalbard. In Möller, P., Hjort, C. \& Ingolfsson, $O$. (eds.): Weichselian and Holocene glacial and marine history of East Svalbard: preliminary report on the PONAM field work in 1991. Lundqua Rep. 35, 161-170.

Andrews, J. T. 1972: Recent and fossil growth rates of marine bivalves, Canadian Arctic, and Late-Quaternary Arctic marine environments. Paleogeogr., Paleoclimatol, Paleoecol. $66,157-176$.

Blomstrand, C. W. 1864: Geognostiska iakttagelser under en resa till Spetsbergen å̊r 1861. Kungl. Svenska Vetenskapsakad. Handl. N.F.4.

Eggertsson, O. 1994: Driftwood as an indicator of relative changes in the influx of Arctic and Atlantic water into the coastal areas of Svalbard. Polar Res. 13, 209-218.

Feyling-Hanssen, R. W. 1955: Stratigraphy of the marine LatePleistocene of Billefjorden, Vestspitsbergen. Norsk Polarinst. Skr. 107. $186 \mathrm{pp}$.

Funder, S. \& Weidick, A. 1991: Holocene boreal molluscs in Greenland - paleoceanographic implications. Paleogeogr. Paleoclimatol. Paleoecol. 85, 123-135.

Gulliksen, S., Heinemeier, J., Heier Nielsen, S., Nydal, R., Rud. N., Skog, G. Skovhus Thomsen, M. \& Landvik, J. Y. 1992: ${ }^{14} \mathrm{C}$-dating of samples collected during the 1991 PONAM expedition to eastern Svalbard. In Möller, P., Hjort, C. \& Ingolfsson. O. (eds.): Weichselian and Holocene glacial and marine history of East Svalbard: preliminary report on the PONAM field work in 1991. Lundqua Rep. 35, 191-198.

Hägg, R. 1950: Kvartära marina fossil frăn Spetsbergen insamlade av svenska expeditioner. Geologiska Fören. Stockholm Förhandl. 72, 331-347.

Heintz, A. 1926: Blåskjell på Spitsbergen. Norsk Geogr. Tidsskr. 9, 74-76.

Hjort, C. \& Funder, S. 1974: The subfossil occurrence of Mytilus edulis $L$. in central East Greenland. Boreas 3, 23-33.

Hjort, C., Adrielsson, L., Bondevik. S., Landvik, J. Y., Mangerud, J. \& Salvigsen, O. 1992: Mytilus edulis on eastern
Svalbard - dating the Holocene Atlantic Water influx maximum. In Möller, P., Hjort, C. \& Ingolfsson, O. (eds.): Weichselian and Holocene glacial and marine history of East Svalbard: preliminary report on the PONAM field work in 1991. Lundqua Rep. 35, 171-175.

Högbom, B. 1913: Om Spetsbergens Mytilustid. Geologiska. Fören. Stockholm Förhandl. 35, 151-156.

Koc, N. \& Jansen, E. 1994: Response of the high-latitude Northern Hemisphere to orbital climate forcing: evidence from the Nordic Seas. Geol. 22, 523-526.

Knipowitsch, N. 1903a: Zoologische Ergebnisse der Russischen Expedition nach Spitsbergen. Mollusca und Brachiopoda IV, Nachtrag. Ánnuaire de Musée Zoologique de l'Academie Imperiale des Sciences de St. Petersbourg 8, 133-143.

Knipowitsch, N. 1903b: Zoologische Ergebnisse der Russischen Expedition nach Spitsbergen. Mollusca und Brachiopoda II \& III. Ánnuaire du Musée Zoologique de l'Academie Imperiale des Sciences de St. Petersbourg 7, 424-445.

Loeng, H. 1991: Features of the physical oceanographic conditions of the Barents Sea. Polar Res. 10, 5-18.

Mangerud, J. \& Gulliksen, S. 1975: Apparent radiocarbon age of recent marine shells from Norway. Spitsbergen and Arctic Canada. Quat. Res. 5, 263-273.

Mangerud, J. \& Svendsen, J. I. 1992: The last interglacialglacial period on Spitsbergen, Svalbard. Quat. Sci. Rev. H, 633-664.

Nansen, F. 1902: The oceanography of the North Polar Basin. The Norwegian North Polar Expedition 1893-1896, Scient. Results 3, Christiania.

Nathorst, A. G. 1884: Redogörelse för den tillsammans med G. De Geer àr 1882 företagna geologiska expeditionen till Spetsbergen. Bihang Kungl. Svenska Vetenskapsakad. Handl. 9,79 pp. Stockholm.

Nathorst, A. G. 1901: Bidrag till Kong Karls Lands geologi. Geologiska Fören. Stockholm Förhandl. 23, 341-378.

Peacock, J. D. 1983: Two finds of modern shells of the common mussle (Mytilus edulis) in Spitsbergen. Porcup. Newsl. 2, 180-181.

Peacock, J. D. 1989: Marine molluscs and Late Quaternary environmental studies with particular reference to the Lateglacial period in Northwest Europe: a review. Quat. Sci. Rev. 8, 179-192.

Polyak, L. \& Solheim, A. 1994: Late- and postglacial environments in the northern Barents Sea west of Franz Josef Land. Polar Res. 13, 197-207.

Salvigsen, O., Forman, S. L. \& Miller, G. H. 1992: Thermophilous molluscs on Svalbard during the Holocene and their paleoclimatic implications. Polar Res. 11, 1-10. 
